\title{
HUNIAN DAN FASILITAS REKREASI PESISIR LAMBOLO
}

\author{
Kevin Adriel ${ }^{1)}$, Sutarki Sutisna ${ }^{2)}$ \\ ${ }^{1)}$ Program Studi S1 Arsitektur, Fakultas Teknik, Universitas Tarumanagara, kevinadriel79@gmail.com \\ 2)Program Studi S1 Arsitektur, Fakultas Teknik, Universitas Tarumanagara, \\ sutarkis@gmail.com
}

Masuk: 05-07-2021, revisi: 30-07-2021, diterima untuk diterbitkan: 23-10-2021

\begin{abstract}
Abstrak
Krisis ekologi merupakan tantangan global umat manusia pada awal abad 21 yang sampai sekarang belum terselesaikan. Pemerintah dan masyarakat di seluruh dunia sangat prihatin dengan kondisi lingkungan yang makin lama kian memburuk. Krisis tersebut merusak seluruh ekologi alam di bumi yang berdampak pada seluruh ekosistem. Pengambilan Sumber Daya Alam (SDA) dengan tidak bertanggung jawab akan berakibat pada kerusakan lingkungan sekitar. Semua makhluk hidup sangat bergantung pada energi bumi, namun jika penanganannya salah maka lingkungan akan rusak akibat pengambilan SDA secara ceroboh. Satu masalah muncul akibat aktivitas penambangan nikel oleh salah satu smelter nikel di Morowali Utara, Sulawesi Tengah yang berdampak pada kerusakan lingkungan terutama di Dusun V Lambolo yang berdekatan dengan pesisir Teluk Tomori. Bangunan yang terbangun harus tidak boleh merusak lingkungan, dan lingkungan yang rusak harus dibenahi menganut aspek-aspek dari Suistainable Development Goals. Tujuan perencanaan ini adalah untuk menghasilkan rancangan dengan me-rehabilitasi kawasan tersebut supaya masalahmasalah disana dapat terselesaikan dengan program penyelesaian masalah serta program rekreasi sosial eksisting dengan desain arsitektur ekologi.
\end{abstract}

\section{Kata kunci: Desain Arsitektur; Kerusakan Lingkungan; Krisis Ekologi; Sumber Daya Alam}

\begin{abstract}
The ecological crisis is a global challenge for mankind at the beginning of the 21st century which has not been resolved until now. Governments and people around the world are very concerned about the worsening environmental conditions. The crisis destroys the entire natural ecology of the earth which affects the entire ecosystem. Taking Natural Resources irresponsibly will result in damage to the surrounding environment. All living things depend on the earth's energy, but if it is handled incorrectly, the environment will be damaged due to careless extraction of natural resources. One problem arose due to nickel mining activities by a nickel smelter in North Morowali, Central Sulawesi, which resulted in environmental damage, especially in Hamlet $V$ Lambolo, which is adjacent to the coast of Tomori Bay. The buildings that are built must not damage the environment, and the damaged environment must be repaired according to the aspects of the Sustainable Development Goals. The purpose of this plan is to produce a design by rehabilitating the area so that the problems there can be solved by problem solving programs and existing social recreation programs with ecological architectural designs.
\end{abstract}

\section{Keywords: Architectural Design; Ecological Crisis, Environmental Damage; Natural Resources, Sustainable Development Goals}

\section{PENDAHULUAN}

\section{Latar Belakang}

Mengembalikan Keadaan lingkungan asri seperti dulu lagi sudah tidak mungkin, namun ada beberapa hal yang seharusnya dapat kita lakukan sebagai makhluk yang paling berperan penting dalam menentukan kondisi lingkungan. Penebangan pohon secara sembarangan membuat hutan akan gundul, lingkungan akan rusak, lalu berimbas pada diri kita sendiri. 
Ketersediaan energi fosil makin menipis, maka perlu dicari energi alternatif yaitu rechargeable battery untuk kendaraan serta alat elektronik. Bahan baku utama batu baterai yaitu nikel, dimana Indoneisia adalah Negara yang memiliki cadangan nikel terbesar di dunia. Di satu sisi penambangan nikel sangat diperlukan untuk memperbanyak eneri alternatif dari baterai, tetapi disisi lain efek dari smelter nikel merusak lingkungan sekitar.

Aktivitas penambangan nikel yang dilakukan oleh smelter nikel yang berdampak besar pada kerusakan lingkungan di Desa Ganda-Ganda, Pesisir Teluk Tomori, terutama di Dusun V Lambolo. Akibatnya, banyak aspek kesehatan, kebersihan, ekonomi, dan soaial. Permasalahan utamanya: kumuhnya pemukiman akibat debu \& lumpur yang mencemari lingkungan pemukiman pesisir, penurunan kualitas air bersih, polusi udara (debu \& asap) dari pabrik smelter nikel.

Berdasarkan latar belakang masalah diatas, maka dirumuskan masalah yaitu Cara memperbaiki kualitas dan kondisi lingkungan Dusun $\mathrm{V}$ Lambolo yang rusak akibat aktivitas penambangan nikel.

Berdasarkan rumusan masalah diatas, tujuan penulisan ini adalah untuk menyelesaikan masalah utama yang terjadi di Dusun $\mathrm{V}$ Lambolo dengan solusi arsitektur berupa desain rehabilitasi tempat serta ditambahkan program penyelesaian masalah yang berlandaskan pada aspek beyond ecology \& SDGs.

\section{Manfaat}

a. Meningkatkan keterampilan dalam mengorganisasi, menyajikan data, dan fakta secara jelas dan sistematis.

b. Mengetahui sumber masalah utamanya dan cara penyelesaiannya.

c. Menambah wawasan arsitektur mengenai cara menyelesaikan masalah di suatu tempat dengan solusi arsitektur.

d. Mengetahui budaya warga Dusun Lambolo.

e. Hasil dari penulisan laporan ini dapat memberikan informasi mengenai desain arsitektur yang berlandaskan beyond ecology \& SDGs, serta terjadinya degradasi kualitas lingkungan di Dusun Lambolo.

\section{Ruang Lingkup}

Bahasan utama dari penulisan ini adalah cara penyelesaian masalah pada Dusun Lambolo yaitu degradasi kualitas lingkungan yang disebabkan oleh aktivitas penambangan nikel, hal itu diselesaikan dengan program filtrasi serta penambahan fungsi rekreasi sosial pada ruang eksisting dan ruang yang kosong.

\section{KAJIAN LITERATUR}

\section{Ekologi}

Cabang ilmu biologi yang mempelajari interaksi antara makhluk hidup dengan makhluk hidup lain dan juga dengan lingkungan sekitarnya. Komponen yang terlibat dalam interaksi ini dapat dibagi menjadi komponen biotik (hidup) dan abiotik (tak hidup).

Ekologi manusia adalah Ilmu yang memperhatikan latar belakang fisik \& budaya manusia.

Aspek yang dipelajari mencakup ekonomi, sosiologi, politik, budaya. Aspek tersebut dipahami melalui latar belakang lingkungan alam \& lingkungan masyarakat. Ekologi manusia terbentuk dari keterkaitan antara unsur alam yang berdampingan dengan kehidupan manusia.

\section{Interaksi Organisme}

Ekologi mempelajari tentang interaksi antar-organisme dan interkasi organisme dengan komponen abiotik. Bentuk interaksi ini berupa cara-cara organisme beradaptasi untuk memanfaatkan lingkungannya. Mahluk hidup membutuhkan energi dan materi yang konstan untuk mempertahankan kehidupanya sehingga interaksi selalu melibatkan materi dan energi. 


\section{Ekosistem}

Suatu sistem ekologi disebut sebagai ekosistem. Susunan dari ekosistem ialah seluruh organisme yang berfungsi bersama dalam suatu wilayah yang berinteraksi dengan lingkungan fisiknya. Interaksi ini membentuk aliran energi yang menghasilkan struktur biota yang jelas dan siklus materi antara bagian hidup dan tak hidup.

\section{Sustainable Development Goals (SDGs)}

Rancangan proyek nantinya akan berlandaskan Sustainable Development Goals (SDGs) yang merupakan suatu rencana aksi global yang disepakati oleh para pemimpin dunia, termasuk Indonesia, guna mengakhiri kemiskinan, mengurangi kesenjangan dan melindungi lingkungan.

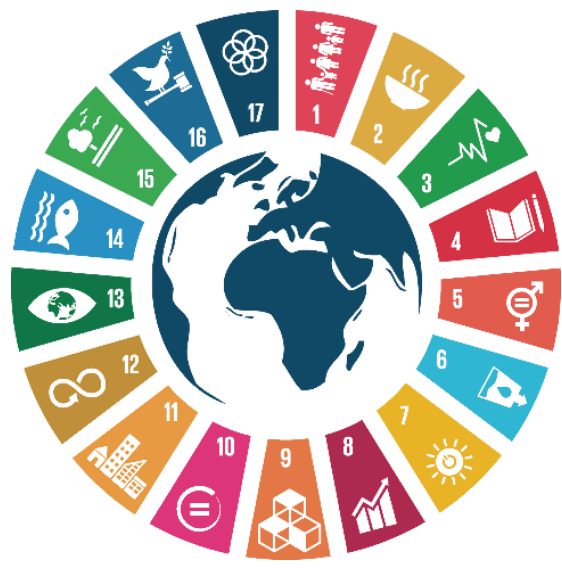

Gambar 1. Aspek SDGs

Sumber: United Nation Foundation

SDGs berisi 17 Tujuan dan 169 Target yang diharapkan dapat dicapai pada tahun 2030.

1. Kemiskinan (Poverty) - Mengakhiri kemiskinan dalam segala bentuknya di setiap tempat.

a. Pangan (Food) - Mengakhiri kelaparan, mencapai ketahanan pangan, perbaikan gizi, dan meningkatkan pertanian yang berkelanjutan.

b. Kesehatan (Health) - Menjamin hidup yang sehat dan meningkatkan kesehatan/ kesejahteraan bagi semua pada semua usia.

c. Pendidikan (Education) - Menjamin pendidikan yang berkualitas, inklusif dan adil, meningkatkan kesempatan belajar sepanjang hayat bagi semua.

d. Perempuan (Women) - Mencapai kesetaraan gender dan memberdayakan semua wanita dan gadis.

e. Air (Water) - Menjamin ketersediaan dan pengelolaan air dan sanitasi yang berkelanjutan bagi semua.

f. Energi (Energy) - Menjamin akses terhadap energi yang terjangkau (terbeli), andal, berkelanjutan, dan modern, bagi semua.

g. Ekonomi (Economy) - Meningkat pertumbuhan ekonomi yang berkelanjutan dan inklusif; partisipasi penuh dalam pekerjaan yang produktif, jenis pekerjaan yang layak bag semua.

h. Infrastruktur (Infrastructure) - Membangun infrastuktur (prasarana) yang awet/ kuat, meningkatkan industrialisasi yang inklusif dan berkelanjutan, mendukung inovasi.

i. Ketidaksetaraan (Inequality) - Mengurangi ketidaksetaraan (inequality) dalam dan antar negara.

j. Pemukiman (Habitation) - Membangun kota dan pemukiman manusia yang inklusif, aman, awet/ kuat, dan berkelanjutan.

k. Konsumsi (Consumption) - Menjamin pola konsumsi dan produksi yang berkelanjutan.

I. Iklim (Climate) - Mengambil langkah-langkah tindakan yang segera untuk mengatasi perubahan iklim dan dampaknya. 
m. Ekosistem Kelautan (Marine Ecosystem) - Melindungi dan menggunakan lautan, laut, dan sumberdaya kelautan secara berkelanjutan untuk pembangunan yang berkelanjutan.

n. Ekosistem (Ecosystem) - Melindungi, memulihkan, dan meningkatkan penggunaan ekosistem bumi secara berkelanjutan, mengelola hutan secara berkelanjutan, menghentikan dan membalik degradasi (kerusakan) tanah, dan kehilangan biodiversitas (keragaman hayati).

o. Kelembagaan (Institutions) - Menciptakan masyarakat yang damai dan inklusif untuk pembangunan yang berkelanjutan, memberikan akses terhadap keadilan bagi semua, membangun lembaga yang efektif, akuntabel (dapat dipertanggungjawabkan), dan inklusif, pada semua level.

p. Keberlanjutan (Sustainability) - Memperkuat cara implementasi dan merevitalisasi (menghidupkan kembali) kemitraan global untuk pembangunan yang berkelanjutan.

\section{Beyond Ecology \& Architecture}

Arsitektur dengan berbagai bentuknya \& ukurannya diciptakan sebagai bagian dari ekologi manusia dan bumi tidak dapat berdiri sendiri, harus dirancang untuk memberikan hal positif baik untuk ekologi lainnya dan juga dirinya. Beyond Ecology adalah Beyond Architecture, bila arsitektur didefinisikan dengan tapak, manusia, fungsi, struktur, selubung. Maka diperlukan suatu ide untuk mengabungkan, menjaga, dan menstabilkan itu semua.

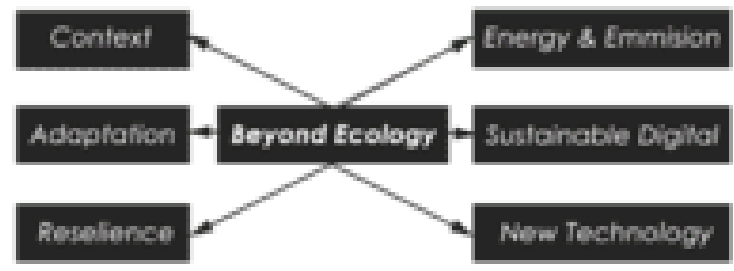

Gambar 2. Aspek Beyond Ecology

Sumber: Sutanto, 2020

Didalam Proyek TGA ini, diambil beberapa dari 6 Aspek Beyond Ecology \& 17 Aspek SDGs yang nantinya dimasukkan ke program arsitektur.

\section{METODE}

\section{Simbiosis}

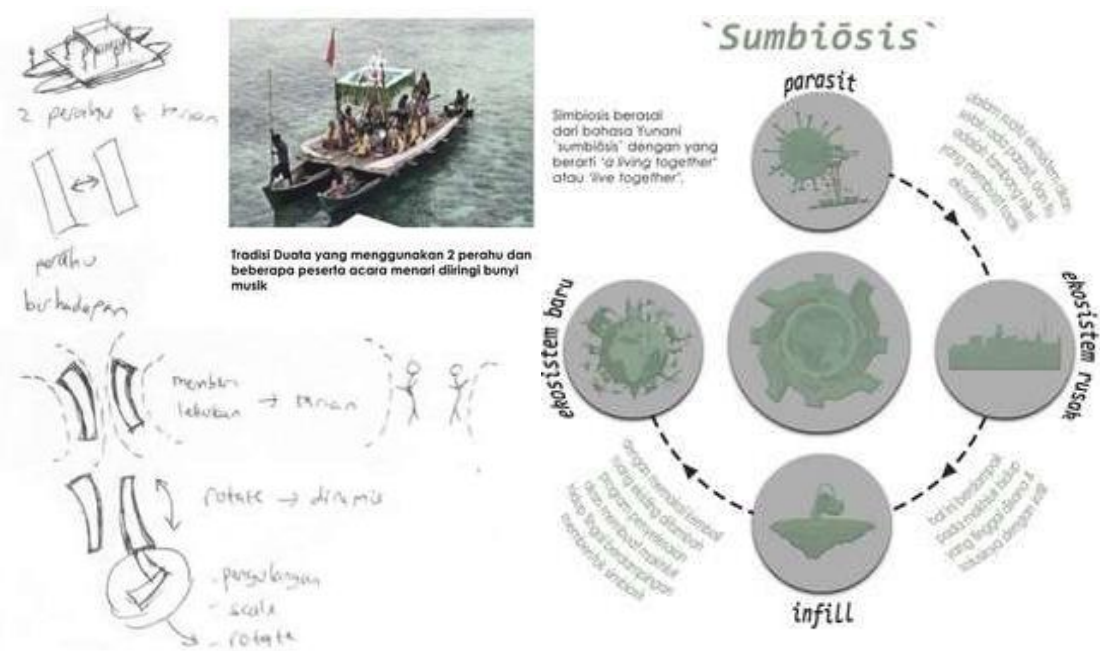

Gambar 3. Metode Desain Sumber: Penulis, 2021 
Apakah tambang, budaya, dan lingkungan pulau-pulau kecil dapat berjalan \& berkembang berdampingan seterusnya? Berkembangbiaknya "semut" industri pertambangan yang semakin memadat seiring dengan terciumnya "gula" bernama nikel secara langsung/ tidak langsung mempengaruhi kondisi lingkungan pesisir laut.

- Dalam suatu ekosistem akan selalu Aada parasit, dan itu adalah tambang nikel yang membuat rusak ekosistem.

- Hal ini berdampak pada makhluk hidup yang tinggal disana \& solusinya dengan infill disana.

- Dengan memakai kembali ruang ekisting ditambah program penyelesaian akan membuat makhluk hidup tingal berdampingan membentuk simbiosis.

- Simbiosis berasal dari bahasa Yunani `sumbiōsis` dengan yang berarti 'a living together' atau 'live together'.

Elemen - elemen lokalitas eksisting lambolo diterapkan pada penerapan perancangan dengan menggunakan struktur panggung, menggunakan material kayu, memakai konsep sama di lao, bangunan dirancang mencorok ke laut.

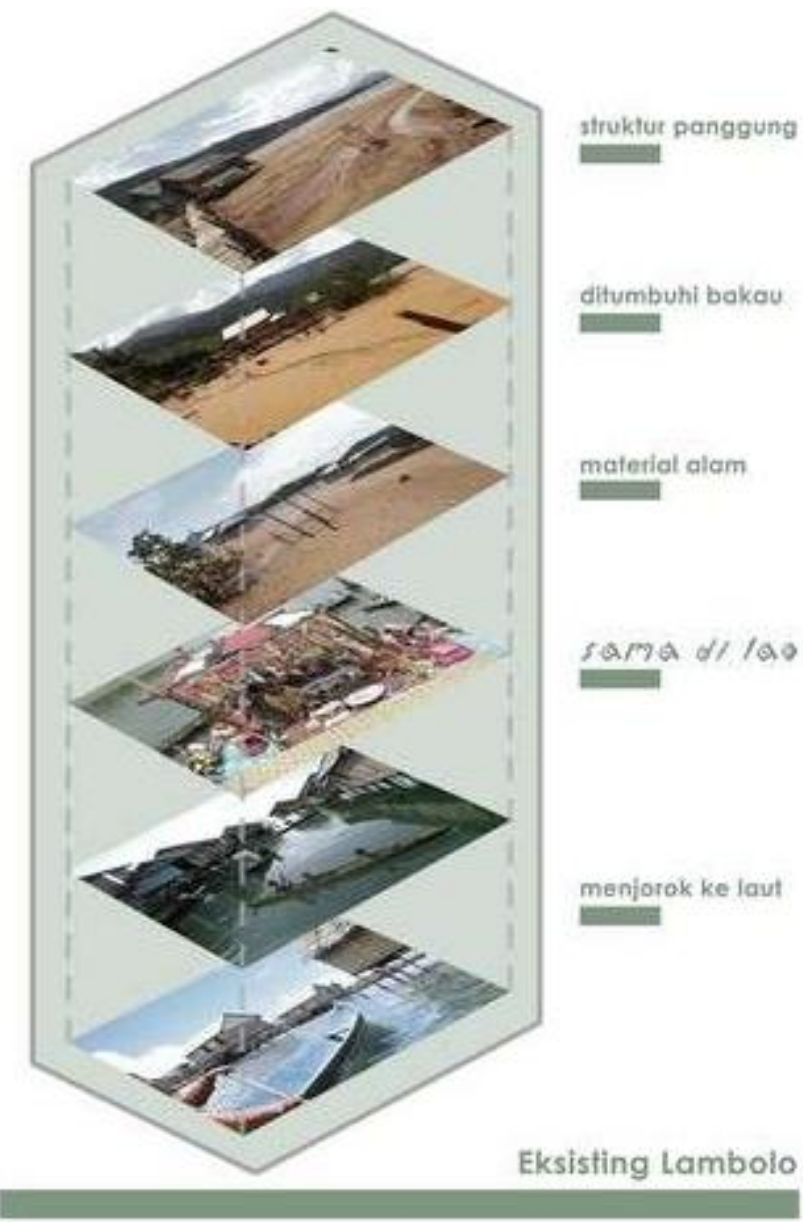

Gambar 4. Penerapan Konsep Lokalitas Sumber: dokumen pribadi

\section{Sama Di Lao}

Filosofi dari Suku Bajo, Sulawesi yang berhuni di daerah pesisir laut. Artinya laut adalah milik orang Bajo, sehingga laut dapat dimanfaatkan menjadi ruang bebas sesuai kegiatan keseharian mereka/ pengembangan hunian. 


\section{Konsep Desain Unit Rumah}

\section{Zoning Vertikal}

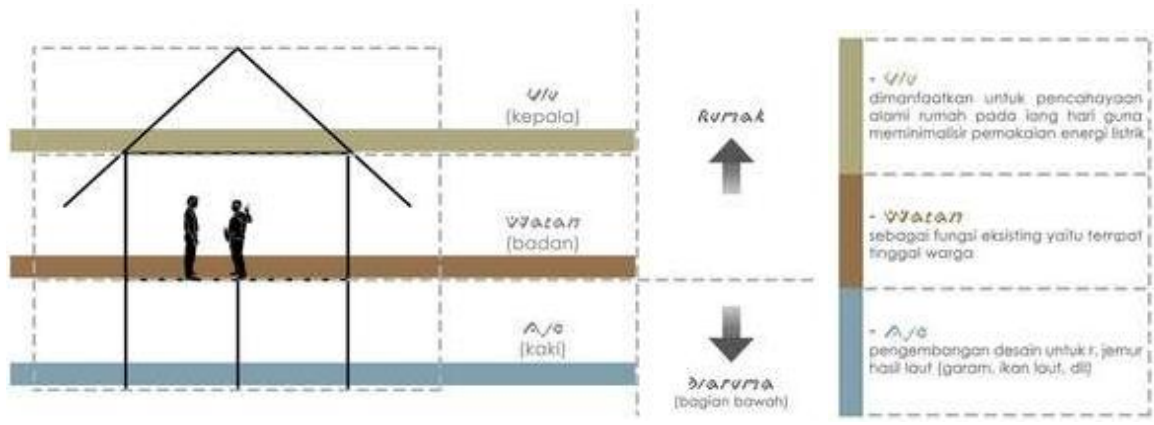

Gambar 5. Zoning Vertikal \& Ide

Sumber: Penulis, 2021

Rumah yang terletak di atas laut memiliki konsep Sama Di Lao dan secara vertical dibagi menjadi 3 bagian yaitu:

- Ulu : bagian kepala

- Watan : bagian badan (tempat ruang-ruang)

- Aje : bagian kaki

Ide

- Ulu dimanfaatkan untuk pencahayaan alami rumah pada siang hari guna meminimalisir pemakaian energi listrik. Solusinya dibagian tengah atap rumah didesain transparan memanjang kebelakang menggunakan bahan kaca sehingga ketika siang cahaya dapat masuk merata ke seluruh ruangan.

- Watan sebagai fungsi eksisting yaitu ruang aktivitas dan tempat tinggal warga yang terdiri dari beberapa ruang sesuai kebutuhan masing - masing penghuni.

- Aje dimanfaatkan sebagai pengembangan desain, bisa untuk $r$. jemur hasil laut (garam, ikan laut, dll) yang dibawa oleh suami.

\section{Hirarki}

Denah

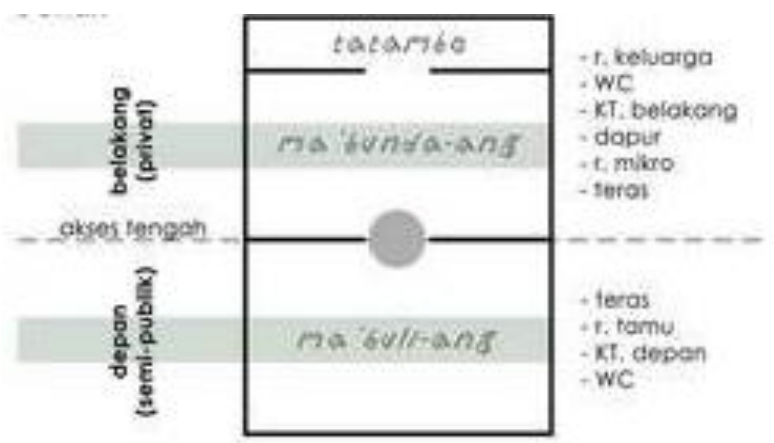

Gambar 6. Hirarki Denah

Sumber: Jurnal "Pola Pemanfaatan dalam Tata Spasial Hunian Suku Bajo yang Berkembang di Kampung Wuring Kota Maumere"

Rumah dibagi menjadi 2 bagian yaidu depan dan belakang. Bagian depan ma'buli-ang, sedangkan bagian belakang $m a^{\prime}$ bunda-ang yang menyatu dengan tatambe (teras belakang). 
Dibagian depat biasanya terdapat ruang teras depan, ruang tamu, kamar tidur 1 , serta WC umum; sedangkan dibagian belakang terdiri dari ruang keluarga, kamar tidur 2, dapur, ruang mirko tambahan (sesuai kebutuhan masing - masing), serta teras belakang yang biasanya digunakan untuk ruang jemur pakaian.

- Jarak antar rumah - rumah warga kisaran 1.5 - 2 meter dengan susunan yang memencar, dan memiliki ruang laut masing - masing yang bebas difungsikan sebagai kebutuhan ruang tambahan.

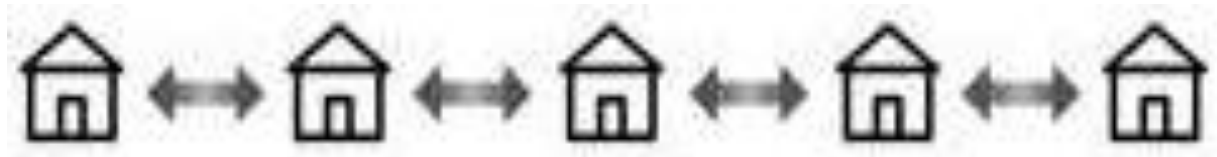

Gambar 7. Jarak antar rumah

Sumber: Jurnal “Pola Pemanfaatan Dalam Tata Spasial Hunian Suku Bajo Yang Berkembang Di Kampung Wuring Kota Maumere"

- Atap pada bangunan berteritis lebar sekitar $>1$ meter menggunakan material atap alami yaitu daun/ nisa juga memakai ijuk. Dibagian teras juga tertutupi oleh teritis atap.

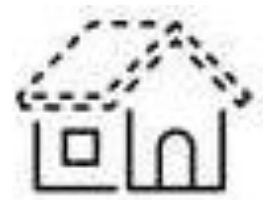

Gambar 8. Teritis Atap

Sumber: Jurnal “Pola Pemanfaatan Dalam Tata Spasial Hunian Suku Bajo Yang Berkembang Di Kampung Wuring Kota Maumere"

- Ruang Jemur terletak menyatu dengan teras belakang (tatambe).

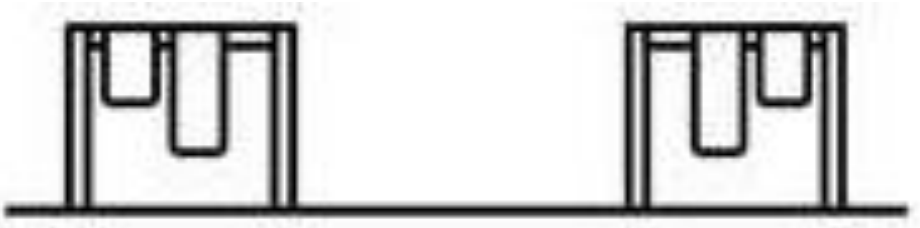

Gambar 9. Ruang Jemur

Sumber: Jurnal “Pola Pemanfaatan dalam Tata Spasial Hunian Suku Bajo yang Berkembang di Kampung Wuring Kota Maumere"

- Orientasi : sama di lao : yang artinya tiap rumah menghadap ke sebuah ruang laut

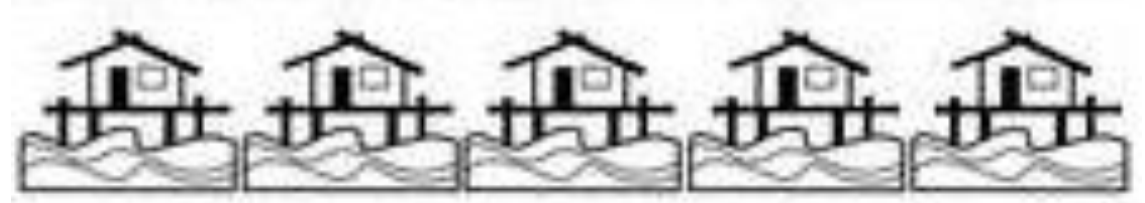

Gambar 10. Orientasi Rumah

Sumber: Jurnal “Pola Pemanfaatan dalam Tata Spasial Hunian Suku Bajo yang Berkembang di Kampung Wuring Kota Maumere"

- Kamar tidur tersusun linear/ berorientai sejajar pada sebuah r. tidur yang ada di depan/ belakangnya. 


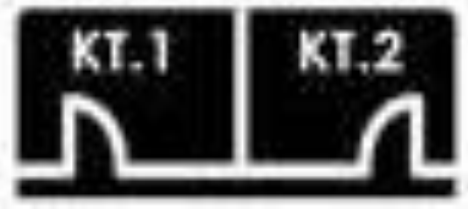

Gambar 11. Kamar Tidur

Sumber: Jurnal "Pola Pemanfaatan dalam Tata Spasial Hunian Suku Bajo yang Berkembang di Kampung Wuring Kota Maumere"

\section{DISKUSI DAN HASIL}

\section{Lokasi Tapak}

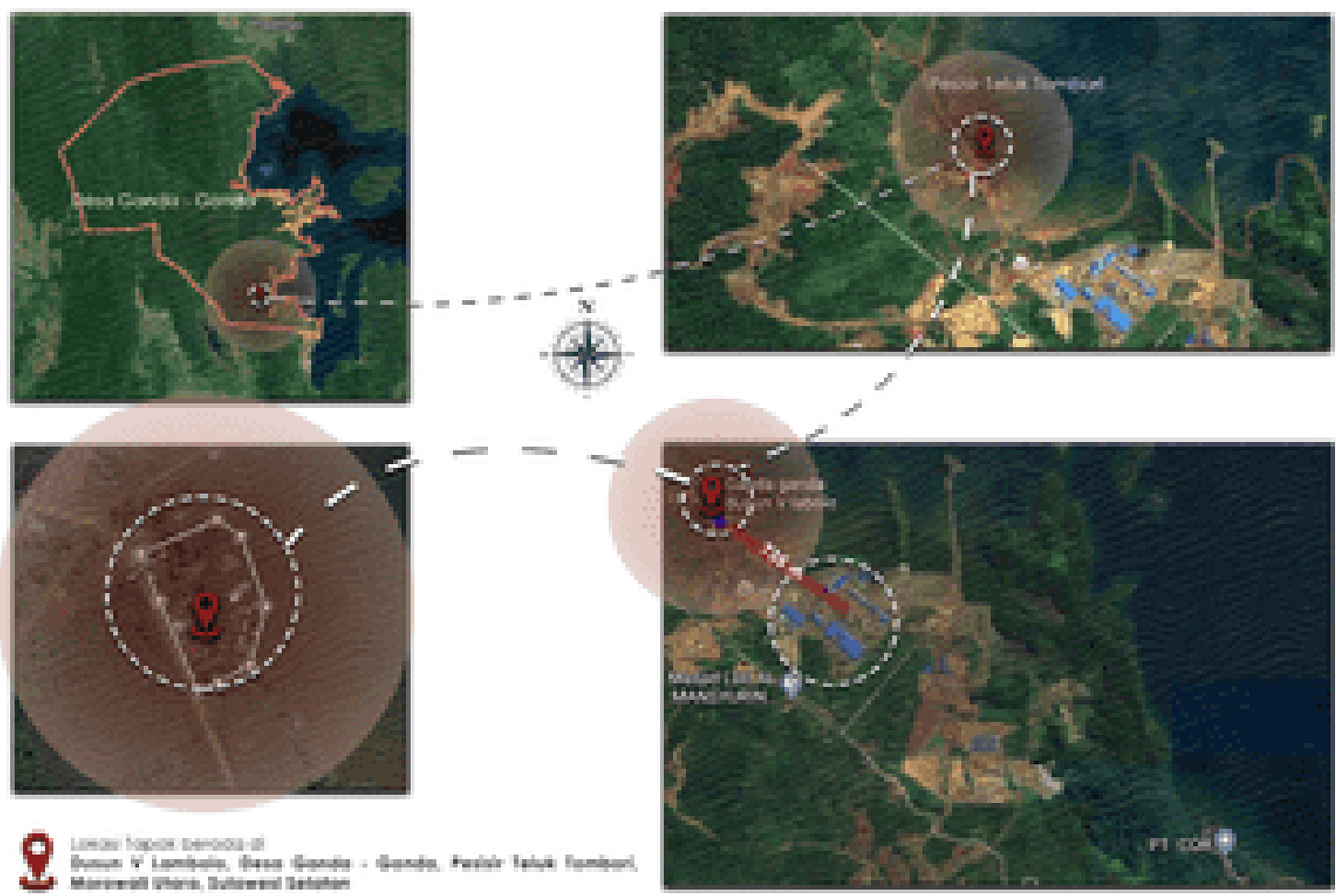

Gambar 12. Detail Lokasi Tapak

Sumber: google maps

Morowali Utara terkenal dengan keindahan gunung, bukit, dan danau, dan pesisir. Beberapa gunung dan danau dijadikan sebagai objek wisata. salah satunya Desa Ganda - Ganda. Banyak sekali lokasi tambang disana, karena salah satu merupakan daerah penghasil mineral logam terbesar se-Idonesia.

Karakteristik pemukiman Dusun Lambolo adalah tempatnya yang menjorok ke pesisir, dikarenakan sebagian penduduk berprofesi sebagai nelayan dan juga pekerja tambang. Kebiasaan yang mereka lakukan adalah bermain di pantai, mencari ikan, berjualan ikan tangkapan di pasar. Suami yang mencari ikan dan istri yang mengatur penjualan untuk perekonimian keluarga. 


\section{Analisis Makro}
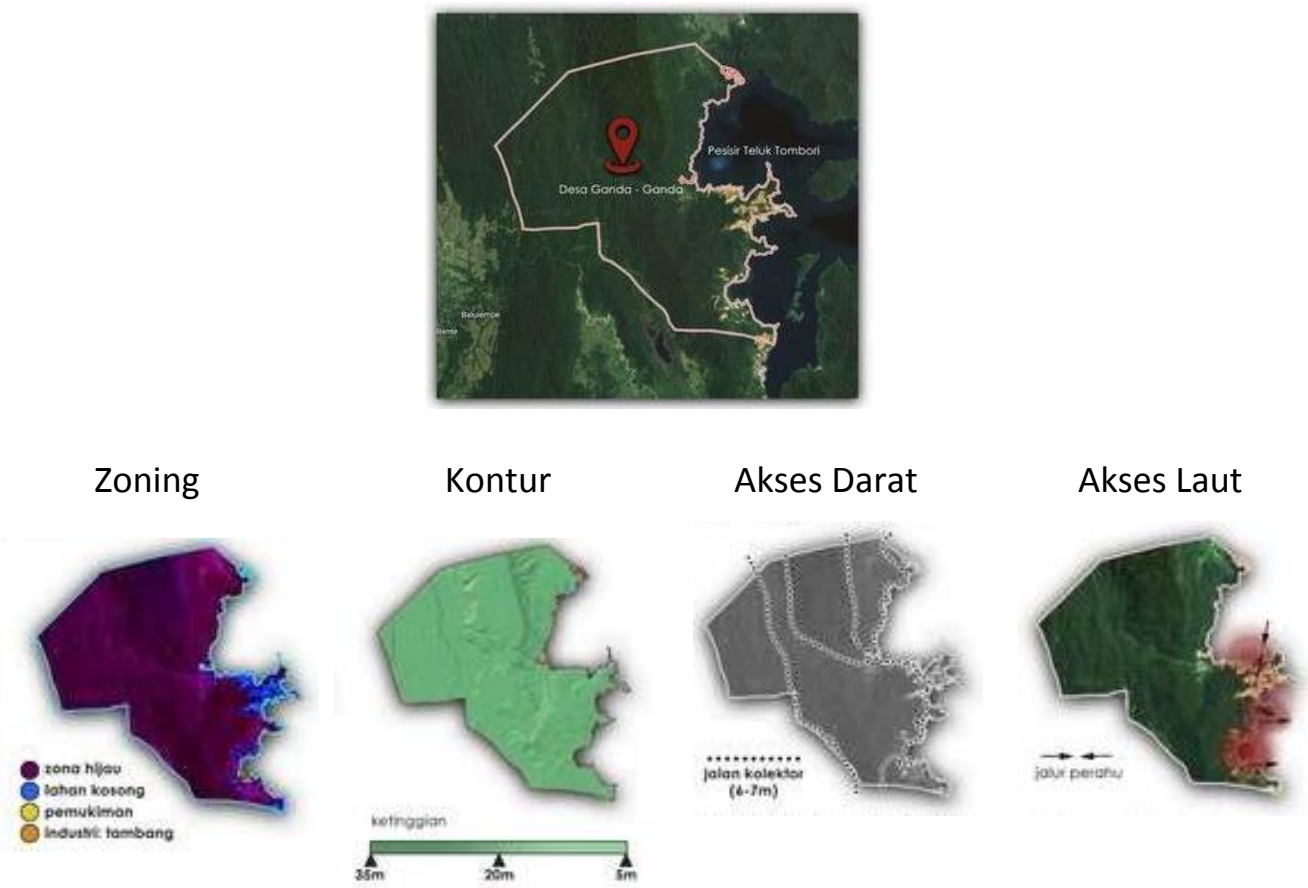

Gambar 13. Ananisis Makro Desa Ganda-Ganda Sumber: google maps

- Zoning: terdapat 4 zona yang didominasi oleh lahan hijau, lahan kosong, pemukiman, dan 1 industri tambang nikel.

- Kontur: Sekeliling Desa berketinggian 5-35 meter.

- Akses transportasi darat: dilalui jalan kolektor selebar 6-7 meter yang terletak di dekat pesisir, akses menggunakan kendaraan.

- Akses transportasi laut: dibeberapa titik terdapat beberapa tempat sebagai persinggahan sementara perahu kecil . 


\section{Analisis Messo}

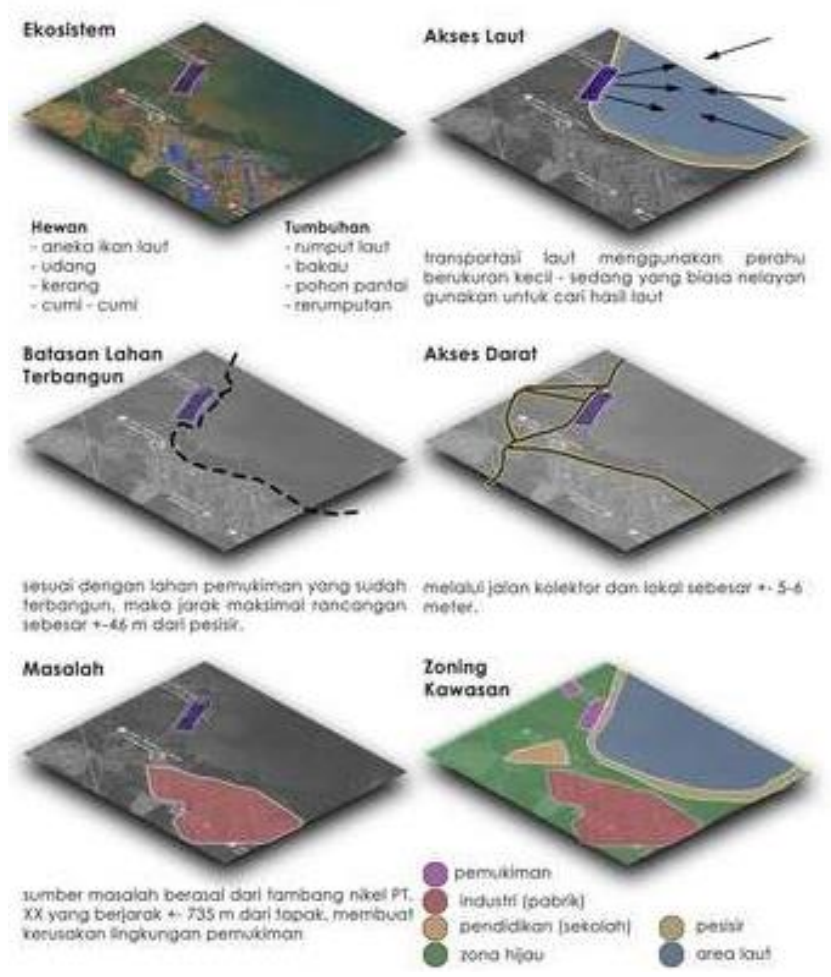

Gambar 14. Analisis Messo

Sumber: google maps

\section{Analisis Mikro}

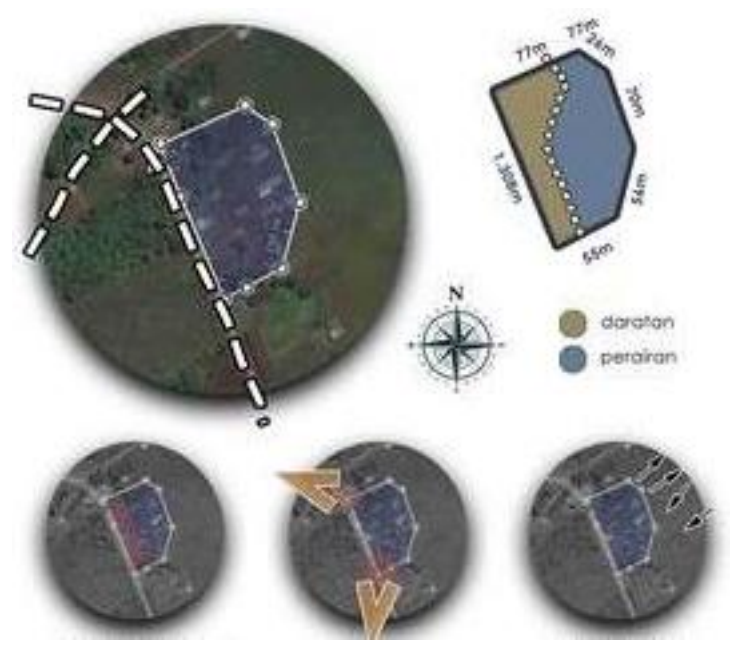

Gambar 15. Analisis Mikro

Sumber: google maps

- sisi timur laut butuh perlindungan mengingat sinar matarari sore pesisir yang lumayan menyengat.

- mengoptimalkan view selatan \& barat laut

- akses jalur laut diletakkan dekan dengan pemukiman

- Strength : berada di lingkungan daratan sekaligus perairan

- Weakness : sangat dekat dengan lokasi penambangan 
- Oportunity : lokasi bisa dijadikan perbaikan \& penyelesaian masalah

- Thread : air \& udara tercemar oleh industri tambang

\section{Lokalitas}

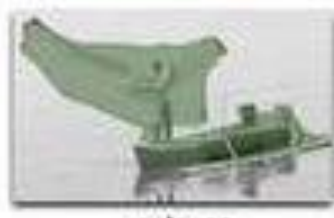

neloyon

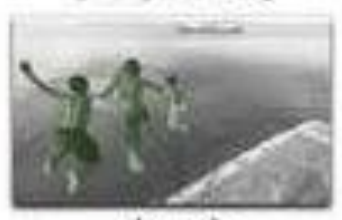

bermain

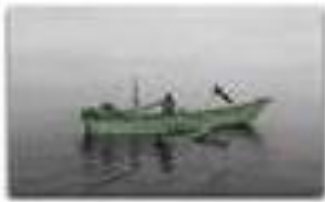

Hentix, peralwo

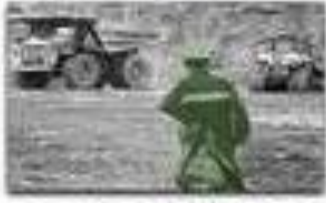

peketjo tombang

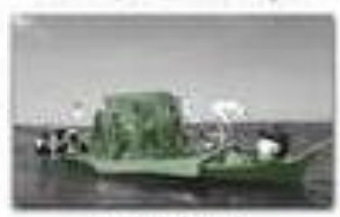

fradhal Duate

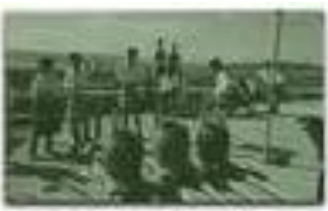

ecara berseme

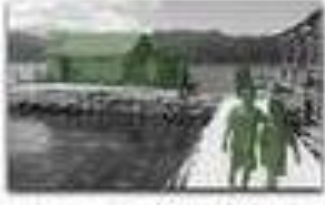

beinublen $\mathrm{k}$ beckumput

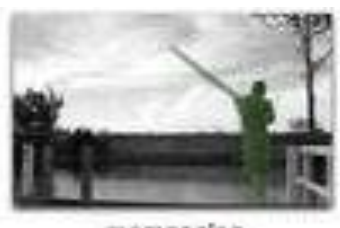

memaneing

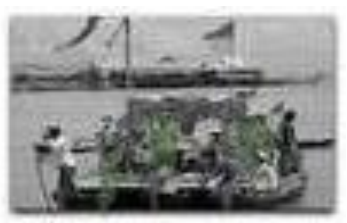

Identik tarian

Gambar 16. Kegiatan Keseharian

Sumber: google maps, Penulis, 2021

Warga Dusun Lambolo kebanyakan berprofesi sebagai nelayan dan pekerja tambang, mengingat di daerah sana juga banyak lokasi tambang serta daerahnya yang dekat dengan pesisir laut. Aktivitas keseharian mereka bermukim, berkumpul, bermain, memancing.

Mereka memiliki suatu tradisi yaitu Duata (acara syukuran) yang identik dirayakan dengan tim penari serta di-iringi oleh musik tradisional gendang di atas 2 sampan tradisional yang berjejeran. Diatas 2 perahu terdapat papan yang menopang aktivitas acara Duata yang sudah dilakukan turun - temurun.

Kegiatan lain yang juga sering dilakukan adalah acara bersama (kawinan, syukuran, pertunjukan kesenian tari, upacara, dan lainnya) tiap $1 / 2$ kali per tahun. Kegiatan tersebut dilakukan di pelataran terbuka/ suatu tempat untuk aktivitas sosial warga, juga sebagai cara untuk membangun keakraban antar penduduk.

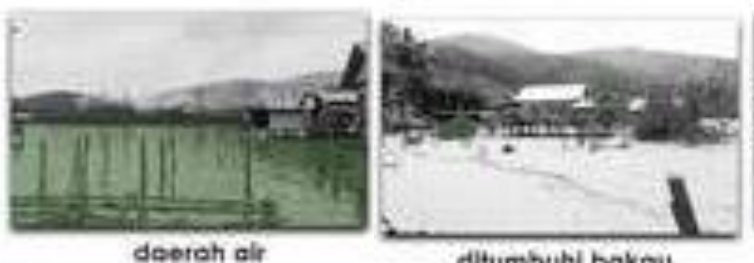

ditumbubi bakou

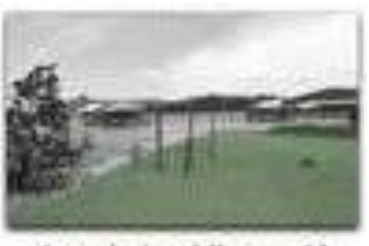

doerah dorat (berpaily)

Gambar 17. Karakteristik Lingkungan

Sumber: google maps, Penulis, 2021

Daerah di lingkungan pemukiman Lambolo terletak pesisir pantai dan menjorok ke lingkungan laut, serta dikelilingi oleh tumbuhan bakau sebagai pendukung ekosistem pantai serta banyak fungsi lain. 


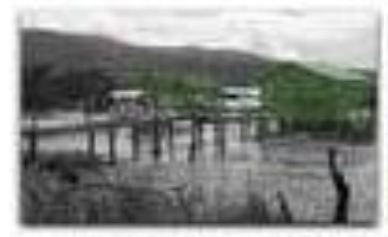

memencar $\&$ ketak

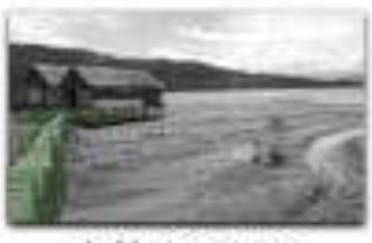

struktur pangevog

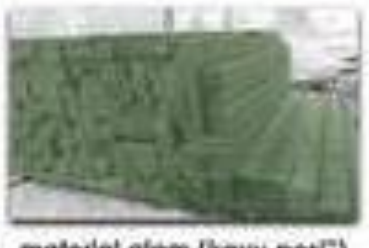

malerlat alom (kayu posi")

Gambar 18. Karakteristik Bangunan

Sumber: dokumen pribadi

Semua bangunan menggunakan struktru panggung setinggi kurang lebih 2-3 meter dari permukaan dasar bangunan, koneksi antar bangunan juga menggunakan jembatan berstruktur panggung dari material kayu. Material bangunan pemukiman serta sorial juga menggunakan kayu, dan dinding bata.

\section{Sintesis}
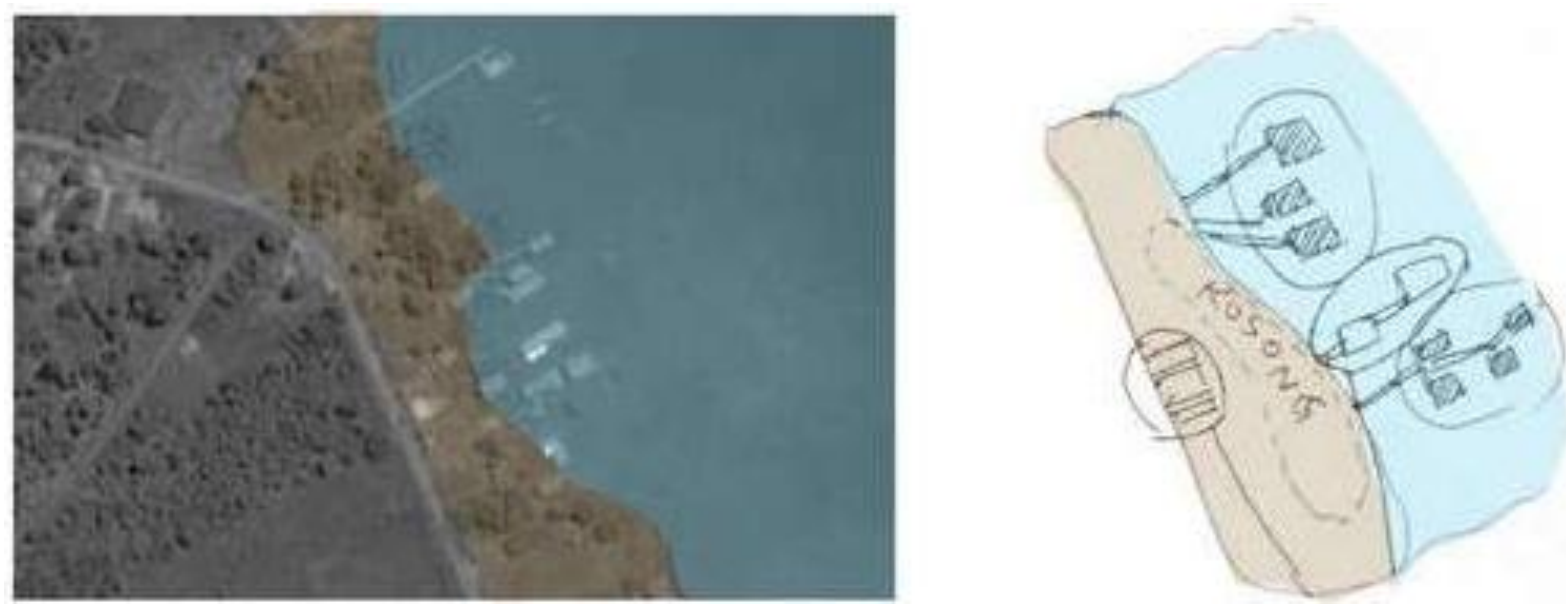

Gambar 19. Sintesis 1

Sumber: google maps, Penulis, 2021

Tapak terbagi menjadi 2 zona, bagian depan daerah berpasir, dan bagian belakang area laut yang diatasnya terdapat bagunan, serta kedua daerah ditumbuhi oleh beberapa tanaman bakau.
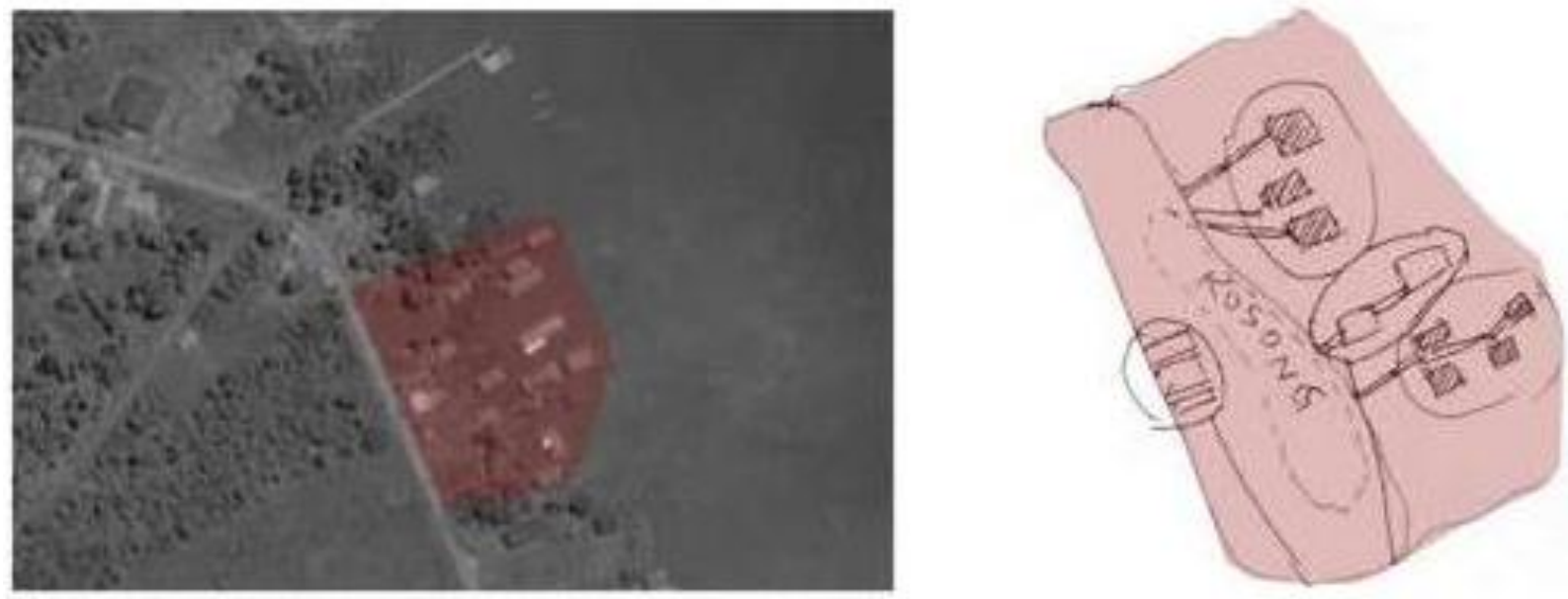

Gambar 20. Sintesis 2

Sumber: google maps, Penulis, 2021 
Batasan tapak diambil sesuai kebutuhan rancangan, serta peraturan bangunan mengukuti kondisi eksisting tapak yang mencakup beberapa pemukiman warga serta fasilitas sosial penunjang.
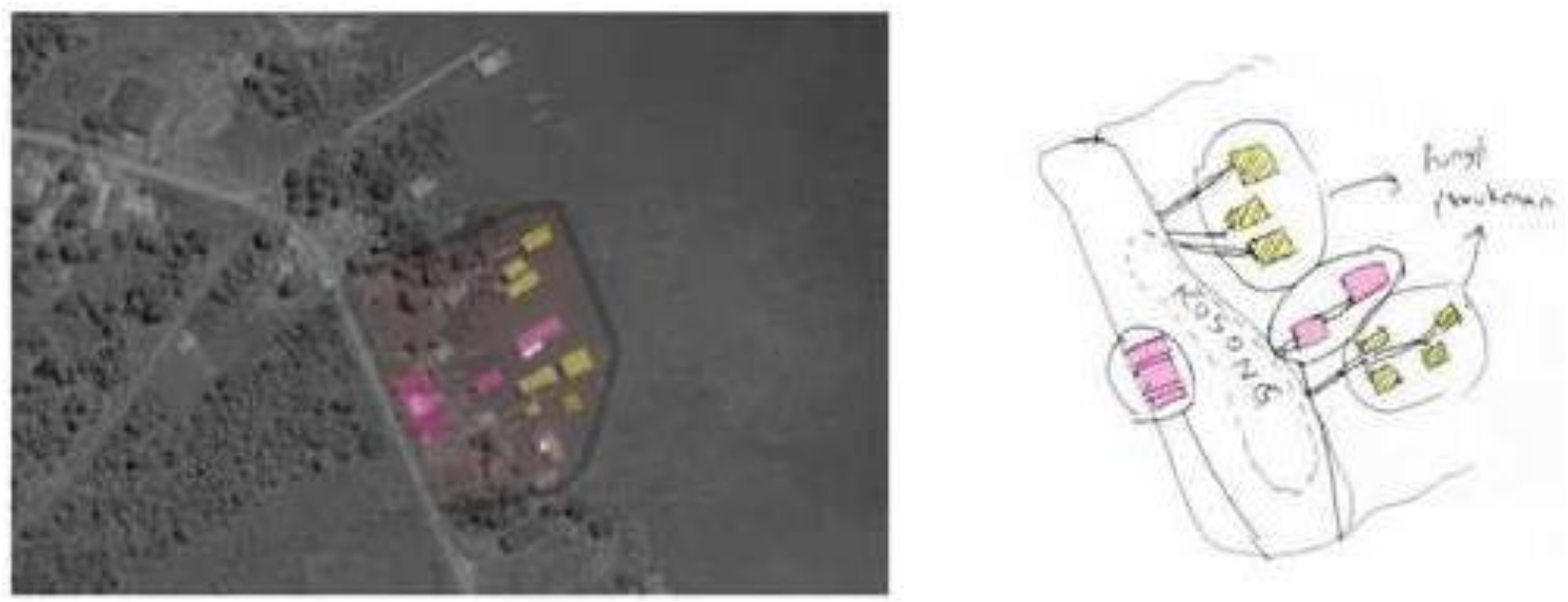

Gambar 21. Sintesis 3

Sumber: google maps, Penulis, 2021

Menempatkan program eksisting yang ada, berupa pemukiman warga dan fungsi sosial penunjang. (kuning: program pemukiman warga), (pink: program fasilitas social penunjang).
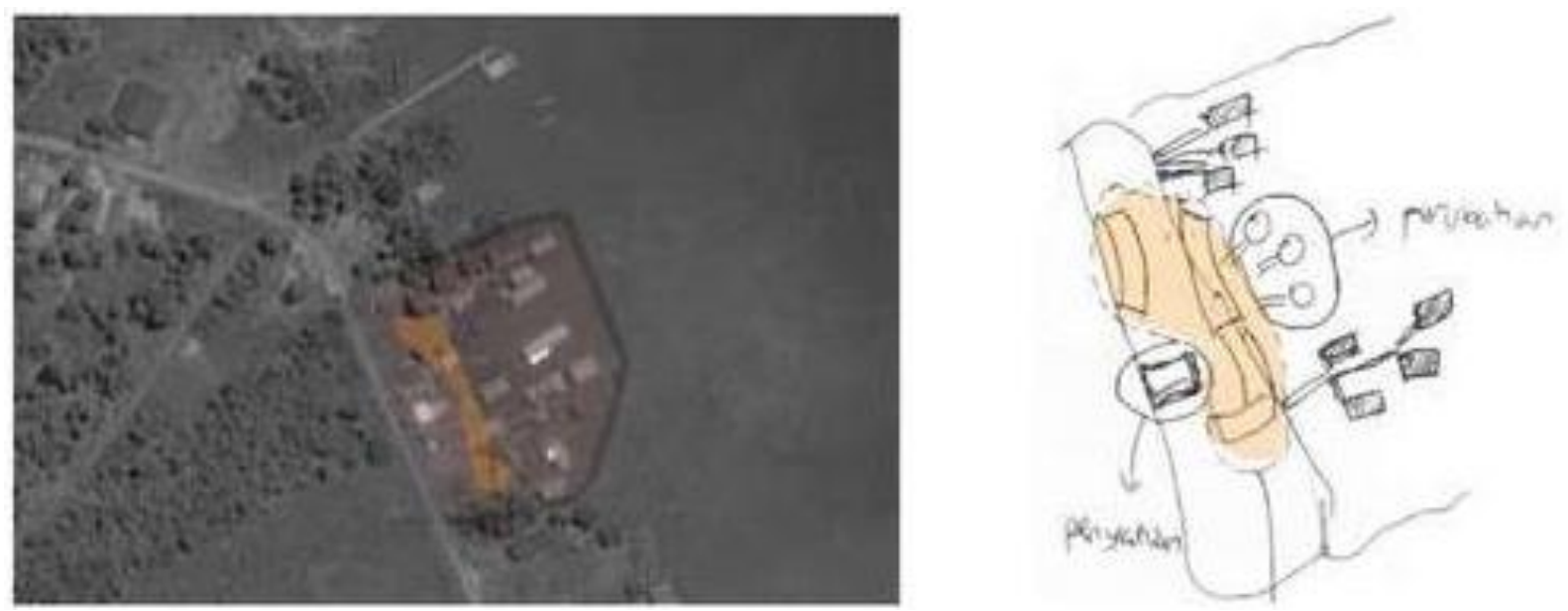

Gambar 22. Sintesis 4

Sumber: google maps, Penulis, 2021

Area tengah yang kosong dimanfaatkan dan dikembangkan sebagai program fasilitas rekreasi sosial serta program penyelesaian masalah yaitu filtrasi air dimana air laut diambil lalu difilter di dalam bangunan filtrasi yang nantinya digunakan untuk kebutuhan air fasilitas sosial.

\section{KESIMPULAN DAN SARAN} Kesimpulan

Indonesia memiliki sumber daya mineral logam nikel yang sangat besar, dan salah satunya adalah nikel sebesar 5.756.362.683 ton (Pusat Sumber Daya Geologi, 2016) yang tersebar di beberapa provinsi, salah satunya Sulawesi Tengah yang memiliki banyak lokasi penambangan. Hasil dari penambangan nikel itu akan di ekspor/ diolah menjadi bahan baku baterai sebagai energi ramah lingkungan penganti energy fosil. Akibat dari aktivitas ini berdampak pada salah satu provinsi di Sulawesi Tengah yaitu Dusun V Lambolo. Dusun tersebut mengalami degradasi 
kualitas lingkungan yaitu: kumuhnya pemukiman akibat debu \& lumpur yang mencemari lingkungan pemukiman pesisir, penurunan kualitas air bersih, polusi udara (debu \& asap) dari pabrik smelter nikel.

Namun kegiatan penambanga ini memang tetap harus berjalan, karena Indonesia turut berpartisipasi mendukung pengembangan energi baterai sebagai penganti energi bahan bakar fosil. Maka solusi yang diberikan dengan cara beradaptasi dengan kondisi lingkungan yang tercemar, dan memperbaikinya sehingga tercipta ekosistem baru dengan memperbaiki program eksisting berupa hunian warga program penyelesaian masalah berupa filtrasi air, dan fasilitas rekreasi sosial yang didesain menggunakan konsep budaya Lambolo berdasarkan aspek SDGs \& beyond ecology yang targetnya adalah para warga hunian serta warga disekitar dusun.

\section{Saran}

Artikel ini masih jauh dari kata sempurna baik dari segi penyusunan, pemakaian bahasa, maupun penulisannya. Untuk pengembangan yang lebuh lanjut, penulis mengharapkan kritik \& saran yang membangun dari semua pembaca guna menjadi acuan agar penulis bisa menjadi lebih baik lagi di masa mendatang.

Semoga artikel ini dapat menambah wawasan para pembaca \& bisa bermanfaat untuk perkembangan dan peningkatan ilmu pengetahuan tentang dunia arsitektur.

\section{REFERENSI}

Gobang A..A.K.S., Sudikno, A. Nugroho, N.M. (2018). Pola Pemanfaatan dalam Tata Spasial Hunian Suku Bajo yang Berkembang di Kampung Wuring Kota Maumere. Jurnal NALARs. 17 (1): 51-64 DOI: https://doi.org/10.24853/nalars.17.1.51-64

Hilmanto, R. (2010). Etnoekologi (PDF). Bandar Lampung: Penerbit Universitas Lampung. ISBN 978-602-8616-60-7.

Susilawati dan Bachtiar, N. (2018). Biologi Dasar Terintegrasi (PDF). Pekanbaru: Kreasi Edukasi. $\mathrm{hlm}$. 166. ISBN 978-602-6879-99-8

_, Definition of ECOLOGY. https://www.merriam-webster.com/dictionary/ecology (dalam bahasa Inggris). Diakses tanggal 2020-11-30

https://sdgs.un.org/goals

https://www.builder.id/

https://www.iea.org/ 